\title{
Effects of a singing program using self-voice monitoring on the intonation and pitch production change for children with cochlear implants
}

\author{
Sung Keong $\mathrm{Kim}^{1} \cdot$ Soo Ji Kim${ }^{2, *}$ \\ ${ }^{1}$ Department of Music Therapy, Soree Ear Clinic, Seoul, Korea \\ ${ }^{2}$ Department of Music Therapy Education, Graduate School of Education, Ewha Womans University, Seoul, Korea
}

\begin{abstract}
The purpose of this study was to examine how a singing program using self-voice monitoring for children with cochlear implants (CI) influences on the intonation and the accuracy of pitch production. To verify and estimate the effectiveness, a program was conducted with participants of 7 prelingual CI users, whose aged between 4 years and 7 years. The program adopted three stages from the self-voice monitoring: Listen, Explore, and Reproduce (LER stage). All participants received 8 singing sessions over 8 weeks, including pre-test, intervention, and post-test. For the pre and post-test, participants' singing of an excerpt of a song "happy birthday" and speaking three assertive sentences and three interrogative sentences were recorded and analyzed in terms of the intonation slopes at the end of the sentences and the melodic contour. From the sentence speeches, we found that the intonation slopes of the interrogative sentences significantly improved as they showed similar patterns with that of the average normal hearing group. Also, in regard to singing, we observed that the melody contour had progressed, as well as the range of pitch production had extended. The positive result from the intervention indicates that the singing program was effective for children with CI to develop the intonation skill and accuracy of pitch production.
\end{abstract}

Keywords: cochlear implants, self-voice monitoring, singing program, children with cochlear implants

\section{1. 서론}

억양은 문장 발화 시 나타나는 음고의 윤곽을 의미하며 소리의 높이인 음고(pitch)와 관련이 깊다. 특히 국어에서 억양은 언어학 적 기능을 가지고 있어 문장 말미에 나타나는 세 가지 연접 억양 유형에 따라 ‘물음'과 ‘대답’을 구분할 수 있다(Beak, 2010). 일반
건청인은 말소리에 나타나는 음도를 쉽게 지각할 수 있기 때문에 억양을 인지하고 산출하는 데 어려움이 없지만, 음고를 제한적으 로 지각하는 인공와우(cochlear implants, 이하 CI) 사용자는 음고 산출 시 건청인과는 구별되는 특징적인 억양 패턴을 보인다.

$\mathrm{Cl}$ 사용자의 말산출 시 대표적 특징은 빈번히 나타나는 내림조 의 억양패턴과 의문문 억양 패턴이다. 특히 의문문에서 $\mathrm{CI}$ 아동의

\footnotetext{
* specare@ewha.ac.kr, Corresponding author

Received 3 February 2020; Revised 24 February 2020; Accepted 4 March 2020

(C) Copyright 2020 Korean Society of Speech Sciences. This is an Open-Access article distributed under the terms of the Creative Commons Attribution NonCommercial License (http://creativecommons.org/licenses/by-nc/4.0) which permits unrestricted non-commercial use, distribution, and reproduction in any medium, provided the original work is properly cited.
} 
문미 억양은 또래의 건청 아동집단에 비해 상승의 정도가 미미하 며, 기울기의 형태와 억양 패턴이 다르게 나타난다고 보고되었다 (Allen \& Ardorfer, 2000; Yoo, 2003). 이러한 특징적인 억양 패턴은 $\mathrm{CI}$ 수술 전 청각장애 아동이 경험하는 영아기의 제한적인 청각적 피드백 경험으로부터 야기될 수 있다(Beak, 2010). 또한 CI 수술 후에도 음도 지각의 한계가 있기 때문에(Gfeller, 2002; Gfeller et al., 2006; Kong et al., 2006; Looi et al., 2012), 비교적 저주파 대역으 로 이루어진 내림조에 대한 청각 및 언어적 경험이 익숙하다는 것이다(Beak, 2010).

따라서 억양 습득 과정에서 청각적 자가피드백이 영아의 초기 발성 발달에서 중요한 단계라는 이며, 이는 조기에 CI 수술을 받은 아동의 경우 청각적 자가피드백과 민감도를 개선하면 발성 발달 에 진전이 나타날 수 있다(Jeon, 2011)는 것을 의미한다. 그러나 CI 아동의 영유아기 및 아동기가 발달과정에서 중요한 시기임에도 불구하고, 발달기 연령의 특징 상 데이터 수집이 어렵고 음성의 질적인 부분에 대한 만족도 평가에 한계가 있어 대부분의 연구는 성인에 초점을 맞추고 있다. 그 예로 성인 CI 사용자를 대상으로 한 연구에서 자가 음성만족도를 조사하였으며, 그 결과 연구 참여 자들은 대체로 만족도가 낮다고 응답하였다. 응답 이유는 자신의 목소리가 코맹맹이 소리 혹은 울리는 소리처럼 들리거나, 목소리 크기가 작고 음성의 왜곡이 일어나기 때문이었다(Lee \& Heo, 2016). 해당 선행연구는 대상이 성인이라는 것에 적용점의 한계가 있지만, CI 착용 이후 음성에 대한 왜곡의 가능성 뿐만 아니라 언 어 발달기에 있는 $\mathrm{CI}$ 영유아들의 말산출 시 자가피드백의 어려움 이 발성 발달 단계에 영향을 미칠 수 있다는 가능성을 시사한다.

억양의 한계점을 극복하기 위한 중재로 언어치료에서는 노래 의 리듬을 활용한 운율치료를 시행하였다. 연구에 보고된 바로 찬트를 활용하거나(Seo, 2010), 리듬의 규칙적인 패턴, 빠르기, 악 센트와 같은 리듬 요소를 활용하여 말하기의 구조적인 특징과 다 양한 표현을 익히도록 하는 전략이 사용되었다(Jang, 2003). 이러 한 선행연구를 통해 억양개선을 위한 음악 요소의 활용이라는 측 면에서 말하기와 노래하기의 유사성을 기반으로 했음을 알 수 있 으나 두 선행 연구 모두 억양을 구성하는 중요한 요소인 선율보다 는 리듬 요소의 반영 비율이 더 높다는 것을 알 수 있다.

한편, CI 아동의 억양개선을 위해서는 억양에 영향을 미치는 음고와 같은 음악적 요소를 포함한 CI 아동의 음악지각 특성을 이해하는 것이 중요하다. 공통적으로 보고된 $\mathrm{CI}$ 아동의 음악지각 은 음색 및 음고와 같은 주파수 중심의 과제 수행력이 건청 아동 에 비해 낮다는 것이며, 반대로 리듬에 대한 반응은 또래의 건청 아동의 민감도와 유사한 수준이라는 것이다(Gfeller, 2002; Gfeller et al., 2006; Kong \& Zeng., 2006; Looi et al., 2012). 이러한 CI 아동의 음악 지각적 한계는 목소리톤과 같은 음도정보의 제한으로 인한 말소리 확인의 어려움으로 이어져 말산출 시 적절한 억양을 산출 하는데 어려움을 보인다(Peng et al., 2008).

따라서 CI 아동의 음악치료의 언어재활에서도 노래부르기가 적 극 활용되고 있으며(Kim \& Jeong, 2017; Kwon, 2016; Oh 2012), 노래 부르기는 가창에 관여하는 신경 및 신체기관이 말산출에도 요구되 어(Thaut, 2005) 음고 및 멜로디 지각 등의 개선을 통해 말소리 지각
에 도움을 줄 수 있다(Gfeller et al., 2008). 또한, 지각적 측면의 개선에 도 불구하고 실제 말산출에서의 직접적인 개선을 위해서는 자가피 드백의 청각적 한계가 고려되어야 하며, 특히 영유아 언어발달 과정 에서 본인이 스스로 자신의 음성에 대한 민감도가 개선되는 것은 궁 극적으로 $\mathrm{CI}$ 아동의 자연스러운 말산출 기능 개선에 매우 중요하다.

따라서 본 연구자는 CI 아동을 대상으로 자가음성 모니터링을 응용한 가창 프로그램을 제공하여 $\mathrm{CI}$ 아동의 억양 개선과 음고 산출 변화에 미치는 영향을 알아보고자 한다. 모든 가창활동은 노래를 녹음하여 들어보는(listen) 첫 번째 단계, 음성의 음고 진행 방향과 숨쉬기 구간 및 음질을 확인하는(explore) 두 번째 단계, 마 지막으로 목소리를 수정하여 의도한대로 재산출하는(reproduce) 세 단계로 구성되어 있다. 또한 노래부르기 시 주된 과제는 이러 한 가창 훈련이 실제 발화 시 적절한 억양으로 의사소통하는데 도움을 줄 수 있도록 의문문의 상행 선율 윤곽과 평서문의 하행 선율 패턴을 제시하였다. 데이터 수집은 사전과 사후에 Praat과 kPhonetica 2. 08 version 음성 분석 프로그램을 이용하여 문장의 억 양기울기를 F0 기울기, Q-tone 기울기, $\mathrm{mA}$ 기울기로 비교분석하 고(Lee \& Seong, 2019) 노래 시 산출된 음도를 비교할 예정이며, 이 에 따른 연구 문제는 다음과 같다.

1. 인공와우 아동의 발화 시 억양기울기 및 음고 윤곽에 개선이 있는가?

2. 인공와우 아동의 노래 시 음고 산출 범위와 선율 윤곽에 변 화가 있는가?

\section{2. 연구방법}

\section{1. 연구참여자}

연구 참여자는 만 4 6세 CI 아동으로 CI 기기를 12 개월 이상 착용한 자이다. 청각장애 외 다른 인지적 장애나 복합장애, 기타 질환이 없으며 발화 시도 및 구화사용이 가능한 경우에 한해 보 호자와 참여자의 참여 동의를 서면으로 받아 연구를 진행하였다. 이에 따라 연구대상자는 기준에 적합한 7명이 선정되었으며, 그 정보는 표 1 에 제시하였다.

표 1. 연구참여대상자 정보

Table 1. Demographic information of children with CIs

\begin{tabular}{c|c|c|c|c}
\hline & 성별 & $\begin{array}{c}\text { 연령 } \\
\text { (개월) }\end{array}$ & $\begin{array}{c}\text { 난청기간 } \\
\text { (개월) }\end{array}$ & $\begin{array}{c}\text { 기기 종류 } \\
\text { 우이 / 좌이 }\end{array}$ \\
\hline 1 & 여 & 75 & 47 & $\mathrm{CI} / \mathrm{EAS}$ \\
\hline 2 & 여 & 53 & 13 & $\mathrm{CI} / \mathrm{CI}$ \\
\hline 3 & 남 & 58 & 30 & $\mathrm{CI} / \mathrm{CI}$ \\
\hline 4 & 남 & 65 & 25 & $\mathrm{CI} / \mathrm{CI}$ \\
\hline 5 & 여 & 48 & 15 & $\mathrm{CI} / \mathrm{CI}$ \\
\hline 6 & 남 & 62 & 15 & $\mathrm{CI} / \mathrm{CI}$ \\
\hline 7 & 남 & 70 & 13 & $\mathrm{CI} / \mathrm{CI}$ \\
\hline \multirow{2}{*}{ 난 }
\end{tabular}

* 난청기간은 청력 보조기 착용전을 의미하며, EAS(Electric acoustic stimulation)로 저주파수 영역의 청력이 남아있을 경우 보청 기를 통해서 소리를 듣게 하고, 고음의 고주파수 영역은 인공 와우를 통해 소리를 듣게 하는 수술.

$\mathrm{CI}$, cochlear implants. 
참여대상자 정보의 난청 기간은 CI 기기 첫 착용 전까지의 기 간을 의미한다. 한편, $\mathrm{CI}$ 집단의 비교군으로 같은 연령의 건청 아 동 6 명을 모집하였다. 대조집단 정보는 표 2에 제시하였으며, 선 정 기준은 서울, 경기 및 인천 지역에 거주하며 읽기가 가능한 건 청 아동이었으며, 최종적으로 아동과 부모가 연구 참여에 동의한 총 6 명의 건청 아동이 참여하였다.

표 2. 건청집단 대상자 정보

Table 2. Demographic information of normal hearing children

\begin{tabular}{c|c|c|c|c}
\hline & 성별 & $\begin{array}{c}\text { 연령 } \\
\text { (개월) }\end{array}$ & 거주지 & 소속 \\
\hline 1 & 여 & 76 & 인천 & 통합학급 \\
\hline 2 & 여 & 65 & 인천 & 통합학급 \\
\hline 3 & 남 & 81 & 인천 & 통합학급 \\
\hline 4 & 남 & 70 & 인천 & 통합학급 \\
\hline 5 & 여 & 71 & 인천 & 통합학급 \\
\hline 6 & 남 & 59 & 인천 & 통합학급 \\
\hline
\end{tabular}

\section{2. 연구도구}

연구자는 본 노래부르기 프로그램 시 참여대상자에게 영향을 미칠 수 있는 배경정보 및 개인변인을 파악하기 위하여 설문지를 활용하였다. 설문지는 $\mathrm{CI}$ 이식 아동의 기초적인 인적사항과 난청 기간 및 청각보조기기 정보를 포함하는 배경정보 5 문항, 음악 활 동 참여 경험 1 문항, 선호 음악 1 문항의 총 7 문항으로 구성되었 다. 배경 설문지는 연구대상자의 보호자에게 연구 참여 동의서와 함께 전달되었다.

음성 데이터 수집을 위하여 Logic Pro X 프로그램을 활용하였 고, 녹음에 사용된 장비는 포커스라이트 스칼렛 솔로(Scarlett Solo) 오디오인터페이스와 아르테시아(Artesia) AMC 10 콘덴서 마이크이며, 해당 기기를 Praat이 설치된 랩탑 인터페이스로 연 결하였다. 또한 억양기울기 측정을 위하여 Praat 음성 분석 프로 그램과 kPhonetica 2.08 version 전문가 음성 분석 프로그램(Seong, 2016)을 활용하였다.

\section{3. 연구설계 및 절차}

본 연구자는 연구를 위하여 2018년 7월에서 8월 2개월간 자료 조사 및 분석, 프로그램 구성을 개발하여 CI 아동 2 명에게 2회로 고안된 예비 중재를 실시하였으며, 예비 중재 참여자는 본 논문 의 프로그램에는 참여하지 않았다. 본격적인 연구대상자 모집은 이화여자대학교 생명윤리위원회의 심의를 거쳐 진행하였다. 중 재 기간은 연구대상자들의 참여 동의서가 모두 수집된 2018년 9 월 17일부터 2018년 11월 2일까지이다. 중재가 진행된 장소는 서 울소재 청각전문병원 및 청각전문교육기관 내 외부인의 방해가 없는 독립적인 공간이었다. 모든 중재는 대상자와 연구자가 마주 보고 앉은 형태로, 개별 진행되었으며, 보호자 또는 보조교사 1 인 이상이 관찰하는 환경에서 진행되었다.

연구중재는 실습 및 인턴쉽 과정을 통해 음악치료중재기술 수 련 및 수퍼비전을 받은 음악치료전공 석사생 연구자 본인이 시행
하였으며, 연구 절차는 한 회기에 $30 \sim 40$ 분이며 주당 $1 \sim 3$ 회, 사 전검사와 사후검사를 포함한 총 8회기로 구성되었다. 사전검사 에서는 대상자의 행동을 관찰하고, 음악선호도 및 배경조사를 시 행하였으며, 기초선을 측정하였다. 기초선은 노래 데이터 생일 축하' 노래와 문장 데이터 6 개 문장을 순차적으로 녹음하였다. 사 전검사이후 중재를 시작하였으며, 마지막으로 사후검사는 사전 검사와 같은 방법으로 데이터를 수집하였다.

2.4. 자가음성 모니터링(Self-Voice Monitoring)을 응용한 가창 프로그램

언어습득 이론에 따르면 언어습득은 타고난 능력 또는 선천적 으로 발생하는 것이 아니라 소리의 자극에 따른 반응 과정을 거 치며 학습되는 것이다(Gardner, 1985). 행동주의적 관점에서 언 어의 습득 과정은 첫째로 유아가 주위의 소리를 듣고 의미와 문 형을 이해하기 위한 침묵의 시간을 겪으며 듣기 능력을 향상시키 고 다음으로 기억한 소리를 모방함으로써 언어를 습득하며 강화 와 반복을 통하여 언어습관이 형성된다(Krashen, 1989). 즉 언어 습득 하는 과정을 요약하면 듣고, 모방하기 위해 다양한 소리 산 출 시도를 한 다음, 주변의 강화를 통해서 의도한 소리와 산출된 소리를 확인하는 반복 과정인 것이다. 이를 통해 연구자는 언어 습득 과정과 일치하는 LER 단계를 구성하였다.

연구에서 시행하는 모든 가창 활동은 아래의 LER 세부 단계에 따라 진행된다. 첫 번째는 연구대상자가 노래를 부른 다음, 노래 를 녹음하여 들어보는(listen) 단계이다. 이 때, 연구대상자는 객 관적으로 자신의 목소리와 산출된 선율 윤곽 패턴을 확인할 수 있다. 두 번째 단계는 산출된 노래가 의도한 음성과 일치하는지 자신의 음성을 확인하는(explore) 단계이다. 이를 통해 연구대상 자는 실제로 자신이 의도한 소리와 산출된 소리의 음고의 진행방 향, 음질, 숨쉬는 구간을 확인해볼 수 있으며, 이를 통해 목소리의 수정 방향을 파악한다. 탐색 과정은 주 참여 아동이 $4 \sim 6$ 세인 관 계로 자동차나 별과 같은 교구를 활용하여 올라가는 상행개념과 내려가는 하행 개념을 매칭하여 소리와 연결하도록 하였다. 마지 막 단계는 목소리를 의도하는 방향으로 노래를 재산출하는(reproduce) 것이다. 이를 통해 연구대상자는 목소리 산출을 위한 다 양한 시도들을 할수 있으며, 필요에 따라아래 그림 1에서 제시된 이 단계를 순환적으로 반복하면서 의도하는 소리를 산출하는 연 습을 하게 된다. 이 과정에서 과제가 되는 음정 간격은 난이도를 고려하여 연속되는 4 개 음의 완전 8 도 간격, 연속되는 3 개 음의 완 전 5도 간격, 마지막으로 장 3 도 간격의 두 음을 단계적으로 제시 하였다. 본 프로그램은 인공와우 대상 음악치료 중재 전문가와 교수진의 자문을 받아 최종 구성하였다. 


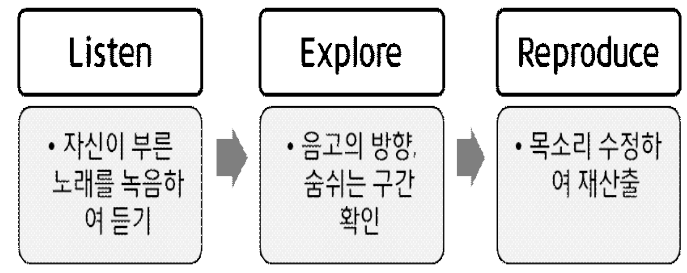

그림 1. LER(Listen-Explore-Reproduce) 단계 Figure 1. Three stages of the singing program

\section{5. 자료수집 및 분석}

데이터 수집을 위한 사전검사와 사후검사에서는 노래와 문장 을 각각 녹음하였다. 녹음 환경 구성은 사전에 점검하여 소음이 $40 \mathrm{~dB}$ 이하이고 독립된 공간을 실험 공간으로 사용하였다. 마이 크는 연구대상자와 연구자사이에 위치한 테이블 위에 놓고 아동 의 입에서 $20 \sim 30 \mathrm{~cm}$ 떨어진 거리에 약 45 도 각도로 배치하였다.

문장 데이터는 글을 읽을 수 있는 대상자에게는 문장 카드를 보여주고 각 문장에서 질문과 대답의 상황에서 같은 문장을 어떠 한 억양으로 말하는지 측정하였다. 본 연구에서 활용된 문장은 선행연구에서 억양기울기 측정을 위한 데이터로 선정된 3 가지 문장을 선정하였다. 이 문장들은 유음과 비음, 모음과 자음을 포 함하여 연구대상자 연령에 친숙한 문장이면서, 발음 구조상 자연 스럽게 읽을 수 있는 단어들로 구성되어있다. 또한 낭독체를 일 상생활의 아동 대화체로 변경하기 위하여 목적격 조사는 생략하 였다(Oh, 2012). 연구자는 예비 중재를 통해 예비 중재 대상자들 과 문장을 녹음해보고, 연구대상자들의 연령과 환경에 익숙한 장 소와 음식으로 두 단어를 수정하였다. 이 과정을 통해 세 문장이 최종 선정되었으며, 연구대상자들은 각 문장을 의문문과 평서문 으로 녹음하였다. 연구에 사용되는 문장은 다음의 표 3 과 같다. 글을 읽을 수 없는 대상자의 경우에는 다양한 상황 그림카드를 보여주어 질문하고 대답하는 ‘질문놀이'를 활용하여 과제를 이 해할 수 있도록 한 다음 의문문과 평서문을 교대로 말할 수 있도 록 하였다.

표 3. 데이터 수집에 사용된 문장

Table 3. Recorded sentences for pre and post-test

\begin{tabular}{c|c}
\hline 의문문 & 평서문 \\
\hline 병원에서 노래해요? & 병원에서 노래해요. \\
\hline 엄마는 라면 좋아해요? & 엄마는 라면 좋아해요. \\
\hline 바다에서 보트 타요? & 바다에서 보트 타요. \\
\hline
\end{tabular}

노래 데이터 수집에 사용된 노래는 '생일 축하’이다. 이 곡은 선행연구에서 사용되어 $\mathrm{CI}$ 아동의 선율재인정확도 중 초등학생 $\mathrm{CI}$ 대상 $100 \%$ 로 선정된 곡들 중 하나이며 $(\mathrm{Oh}, 2015)$, 선율 산출 정 확도를 측정할 때 중재 후 음정산출의 효과성이 검증되었다(Kim \& Chong, 2017). '생일축하' 노래에서는 상행과 하행 패턴과 도약 과 순차 진행이 모두 포함된 세 번째(phrase) 프레이즈 구간을 데 이터로 수집하였으며, 악보는 아래의 그림 2와 같다.

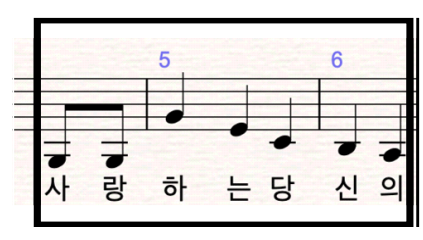

그림 2. '생일 축하' 노래의 데이터 수집 구간(세 번째 프레이즈)

Figure 2. Recorded third phrase of the 'Happy Birthday'

데이터 분석은 문장의 경우 Praat과 kPhonetica 2. 08 version 음 성 분석 프로그램을 이용하여 억양기울기를 세 가지 기울기 척도 (F0 기울기, Q-tone 기울기, $\mathrm{mA}$ 기울기 값)를 구하였으며, 문장의 음절과 가사를 레이블링 하여 각 음절의 주파수 $(\mathrm{Hz})$ 와 발화길이 (duration)를 수집하였다. F0 기울기는 regression slope을 의미하 며, qtone slope은 측정된 각 주파수를 24*log2(F0/denominator) 공 식을 사용하여 qtone 값으로 변경한 후 측정한 regression slope이 며 본 통계에서 저자는 중앙값을 선택하여 표기하였다. $\mathrm{mA}$ 기울 기는 측정구간의 프레임단위 주파수 절대값차의 총합을 해당 측 정구간으로 나눈 ‘억양굴곡 변이량 기울기'를 의미한다(Lee \& Seong, 2019). 노래 데이터의 경우에는 Praat과 Logic Pro X를 활용 하여 노래를 레이블링하고, 가사 별로 구간을 조정하여 기본 주 파수를 측정하였다. 이를 토대로 비모수적인 방법인 Wilcoxon signed-rank test(윌콕슨 부호순위 검정)를 사용하여 인공와우 아 동 집단의 전후 변화를 통계분석 하였으며, 사후검사에서 나타난 값과 건청아동 집단을 비교분석하였다.

\section{3. 결과}

\section{1. 문장 발화 시 나타나는 억양의 변화}

연구자는 중재의 효과성을 확인하기 위해 사전검사와 사후검 사를 비교한 다음 두 검사에서 도출된 데이터를 건청집단 평균을 비교할 수 있도록 참고 제시하였다. 의문문의 경우 '노래해요?' 와 ‘보트 타요?’ 문장의 문미 2 음절 억양이 건청 아동 기울기와 유 사해진 것을 확인할 수 있다. '노래해요?' 문장에서는 문미 2 음절 (해-요?)의 기울기가 건청 아동 집단과 마찬가지로 상행하는 윤 곽으로 나타났다. $\mathrm{F} 0$ 기울기 값의 0 에서 0.3 값으로 증가하여 건 청 집단 대비 0.3 으로 차이가 감소하였고, Q-tone 기울기 값과 $\mathrm{mA}$ 기울기 값도 평행하던 윤곽에서 상행하는 값으로 각각 $0.6,104.0$ 만큼 증가하여 문미 2음절이 상행하는 패턴으로 건청 집단의 기 울기 값에 가까워졌다. 다른 두 문장의 결과도 사후에 기울기 값 이 증가하여 보다 상승하는 윤곽을 보였으며, 건청 아동 기울기 값과의 대비 값이 줄어들어 유사한 억양 패턴의 윤곽을 나타내었 다. 의문문 문미 음절 간 산출 음고의 평균 값은 표 4 와 같다. 
표 4. 의문문에 대한 건청 $(\mathrm{NH})$ 집단과 CI 집단 사전(CI pre), 사후(CI post) 검사의 문미음절 당 평균 주파수 $(\mathrm{Hz})$ 의 기울기 비교

Table 4. Comparison of the interrogative sentences' the average frequency per syllable $(\mathrm{Hz})$ between the groups

\begin{tabular}{|c|c|c|c|c|c|}
\hline $\begin{array}{l}\text { 문미 } \\
\text { 음절 }\end{array}$ & 기울기 & $\begin{array}{c}\mathrm{NH} \\
(\mathrm{N}=6)\end{array}$ & $\begin{array}{l}\text { CI pre } \\
(\mathrm{N}=7)\end{array}$ & $\begin{array}{c}\text { CI post } \\
(\mathrm{N}=7)\end{array}$ & $p$-value \\
\hline \multirow{6}{*}{$\begin{array}{l}\text { 노래 } \\
\text { 해-요? }\end{array}$} & \multirow{2}{*}{ F0 } & 0.3 & 0.0 & 0.3 & 0.469 \\
\hline & & & & $(\mathbf{\Delta} 0.3)$ & \\
\hline & \multirow{2}{*}{ qtone } & 3.7 & 2.7 & 3.3 & 0.578 \\
\hline & & & & $(\mathbf{\Delta} 0.6)$ & \\
\hline & \multirow{2}{*}{$\mathrm{mA}$} & 202.8 & 192.9 & 296.9 & 0.015 \\
\hline & & & & $(\mathbf{\Delta} 104.0)$ & ${ }^{*} p<0.05$ \\
\hline \multirow{6}{*}{$\begin{array}{l}\text { 좋아 } \\
\text { 해-요? }\end{array}$} & \multirow{2}{*}{ F0 } & 2.1 & 0.4 & 0.5 & 0.812 \\
\hline & & & & $(\boldsymbol{\Delta} 0.1)$ & \\
\hline & \multirow{2}{*}{ qtone } & 5.4 & 3.6 & 3.9 & 0.297 \\
\hline & & & & $(\boldsymbol{\Delta} 0.3)$ & \\
\hline & \multirow{2}{*}{$\mathrm{mA}$} & 472.8 & 290.3 & 269.9 & 0.688 \\
\hline & & & & $(\nabla 20.4)$ & \\
\hline \multirow{6}{*}{$\begin{array}{l}\text { 보트 } \\
\text { 타-요? }\end{array}$} & \multirow{2}{*}{ F0 } & 1.6 & 0.3 & 0.6 & 0.375 \\
\hline & & & & $(\mathbf{\Delta} 0.3)$ & \\
\hline & \multirow{2}{*}{ qtone } & 4.5 & 3.5 & 3.7 & 1.000 \\
\hline & & & & $(\boldsymbol{\Delta} 0.2)$ & \\
\hline & \multirow{2}{*}{$\mathrm{mA}$} & 453.4 & 273.4 & 276.4 & 0.938 \\
\hline & & & & $(\boldsymbol{\Delta} 3.0)$ & \\
\hline
\end{tabular}

CI, cochlear implants.

$\mathrm{NH}$, normal hearing.

평서문에서도 집단 간 음고 평균의 윤곽에서 문미 2음절의 하 행 패턴이 공통적으로 변화하였다. 사전검사 시에는 모든 문장의 문미 2음절의 기울기 값이 F0 기울기 0.3, Q-tone 기울기 2.6, mA 기울기 429.3으로 상행하는 억양 패턴으로 나타났으나사후에는 완만하게 평행하는 윤곽을 띄거나 하행하는 움직임으로 변화되 었다. 이러한 결과는 건청집단의 문미 2 음절과 윤곽 패턴과 유사 하다는 것을 의미한다. 건청집단과 실험집단의 사전 사후 검사 시 나타난 음절 간 기울기를 비교한 값은 표 5 에 표기하였다.
표 5. 평서문에 대한 건청 집단(NH)과 CI 집단 사전(CI pre), 사후(CI post) 검사의 문미음절 당 평균 주파수 $(\mathrm{Hz})$ 의 기울기 비교

Table 5. Comparison of the assertive sentences' the average frequency per syllable $(\mathrm{Hz})$ between the groups

\begin{tabular}{|c|c|c|c|c|c|}
\hline $\begin{array}{l}\text { 문미 } \\
\text { 음절 }\end{array}$ & 기울기 & $\begin{array}{c}\mathrm{NH} \\
(\mathrm{N}=6)\end{array}$ & $\begin{array}{l}\text { CI pre } \\
(\mathrm{N}=7)\end{array}$ & $\begin{array}{c}\text { CI post } \\
(\mathrm{N}=7)\end{array}$ & $p$-value \\
\hline \multirow{6}{*}{$\begin{array}{l}\text { 노래 } \\
\text { 해-요. }\end{array}$} & \multirow{2}{*}{ F0 } & -0.3 & 0.4 & -0.1 & 0.109 \\
\hline & & & & $(\boldsymbol{\nabla} 0.5)$ & \\
\hline & \multirow{2}{*}{ qtone } & 3.1 & 2.7 & 2.7 & 1.0 \\
\hline & & & & $(\boldsymbol{\nabla} 0.0)$ & \\
\hline & \multirow{2}{*}{$\mathrm{mA}$} & 109.1 & 274.0 & 176.3 & 0.016 \\
\hline & & & & $(\nabla 97.7)$ & ${ }^{*} p<0.05$ \\
\hline \multirow{6}{*}{$\begin{array}{l}\text { 좋아 } \\
\text { 해-요. }\end{array}$} & \multirow{2}{*}{ F0 } & 0.4 & -0.1 & -0.3 & 0.938 \\
\hline & & & & $(\boldsymbol{\nabla} 0.2)$ & \\
\hline & \multirow{2}{*}{ qtone } & 4.4 & 4.8 & 3.6 & 0.031 \\
\hline & & & & $(\nabla 1.2)$ & ${ }^{*} p<0.05$ \\
\hline & \multirow{2}{*}{$\mathrm{mA}$} & 203.5 & 251.9 & 226.1 & 0.219 \\
\hline & & & & $(\mathbf{\nabla} 25.8)$ & \\
\hline \multirow{6}{*}{$\begin{array}{l}\text { 보트 } \\
\text { 타-요. }\end{array}$} & \multirow{2}{*}{ F0 } & -1.1 & 0.4 & -0.2 & 0.078 \\
\hline & & & & $(\boldsymbol{\nabla} 0.6)$ & \\
\hline & \multirow{2}{*}{ qtone } & 3.5 & 3.3 & 3.2 & 0.578 \\
\hline & & & & $(\boldsymbol{\nabla} 0.1)$ & \\
\hline & \multirow{2}{*}{$\mathrm{mA}$} & 215.3 & 291.3 & 212.4 & 0.297 \\
\hline & & & & $(\mathbf{\Delta} 78.9)$ & \\
\hline
\end{tabular}

CI, cochlear implants.

$\mathrm{NH}$, normal hearing.

\section{2. 노래에서 나타난 음도의 변화}

노래 데이터는 중재 후 $\mathrm{CI}$ 아동 그룹의 산출 음도에 변화가 있 는지 알아보기 위해 건청 아동의 산출 음도와비교하여 변화치가 정상 발달 아동과 유사한 경향을 보이는지 확인하였다. 또한, 각 대상자들에게 편안한 음도로 <생일 축하> 노래를 부르게 하여, 연구대상자들이 산출한 첫 시작 음도의 주파수 평균을 구하여 평 균 음으로 변환 했을 때 가장 가까운 12 음계 음을 도출하여 절대 음정 간격과의 음도차이를 확인하였다.

세 번째 프레이즈의 구간 3은 특히 도약이 많고 명확한 선율 윤 곽이 드러나는 구간이며, 따라서 CI 집단의 사전과 사후의 결과 를 비교하기 적절한 구간으로 사료된다. 결과 표 6 를 살펴보면 건 청 아동 그룹의 음절 당 음고 주파수평균의 범위는 $115.9 \mathrm{~Hz}$ 로 기 대되는 절대음도의 주파수 간격 $196 \mathrm{~Hz}$ 보다는 좁았으나, CI 아동 그룹의 사전검사 시 산출 음고 간격 $50.2 \mathrm{~Hz}$ 보다는 2 배 이상 넓은 것으로 나타났다. 또한, 선율 윤곽을 확인하기 위한 그래프는 그 림 3에 제시하였다. 사전 검사 시에는 ‘사-랑', ‘는-당’의 가사 구 간에서 음고 반전이 일어났으며 전체적으로 음고의 움직임이 적 은 선율윤곽이었다. 반면에사후검사에서는 대조집단과 거의 일 치하는 선율 윤곽을 나타내었다. 
표 6. 평서문에 대한 건청 집단(NH)과 CI 집단 사전(CI pre), 사후(CIpost) 검사의 음절 당 평균 주파수(Hz)의 차이 비교 Table 6. Comparison of the average frequency per syllable $(\mathrm{Hz})$ between the groups

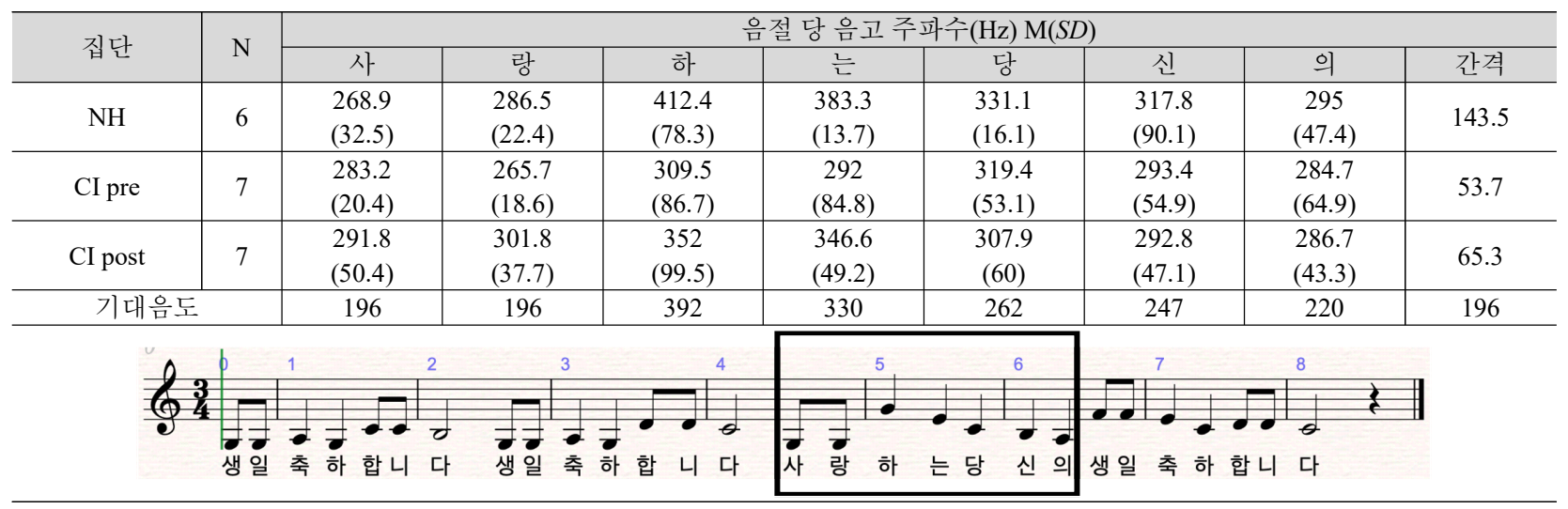

CI, cochlear implants.

$\mathrm{NH}$, normal hearing.

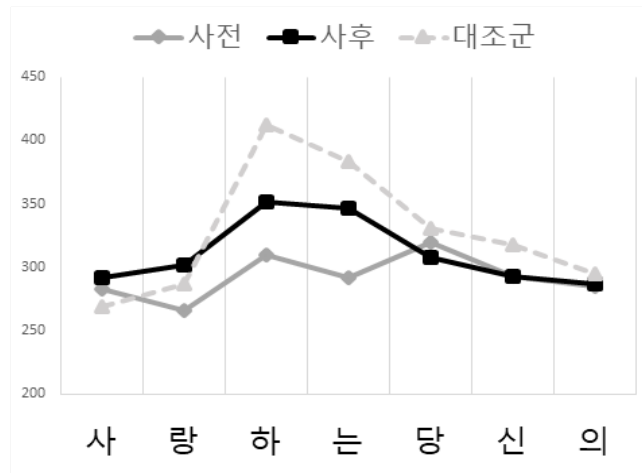

그림 3. 집단 간 사전·사후 시 나타난 산출 음도의 선율윤곽

Figure 3. Melodic contour in pre and post test

\section{4. 논의 및 결론}

위의 결과를 토대로 한 해당 연구의 논의사항은 다음과 같다. 첫째, 본 노래부르기 프로그램은 LER(listen-explore-reproduce) 단계를 CI 아동에게 최초로 시도한 음악치료 가창 프로그램으로, 목소리 피드백과 자가수정을 통해 CI 아동의 산출 음도 간격을 효과적으로 확장시킬 수 있었다. 특히, LER 과정에서 대상자들 이 선율윤곽이 방향을 확인한 후 의도하는 선율윤곽 패턴으로 노 래하기 위해 거치는 자가수정이 청각장애아동이 가장 많이 사용 하는 의사소통 회복전략이기 때문에(Tye-Murray, 2003) 가창 시 에도 효과적으로 활용할 수 있었다. 또한 LER 과정은 제 2의 언어 를 배울 때 조음 학습 전략에 활용되는 Eckstein(2007)의 발음 습 득 구조와 유사하다. 발음 습득 구조는 다음의 네 가지 단계로 진 행된다. 첫째는 목표 언어의 발음에 대한 구체적인 경험을 의미 하는 ‘입력/연습(Input/Practice)' 단계, 둘째는 자신의 발음과 모 어 화자 발음의 차이를 인지하여 발음을 학습하는 ‘피드백/주목 (Feedback/Noticing)' 단계, 셋째는 발음의 피드백 과정을 통해 목표 발음과의 불일치성을 극복하려는 '가설형성(Hypothesis forming)' 단계, 마지막으로 새로운 가설에 따라 기존의 발음과 다르게 발 음을 실행해보는 '가설검증(Hypothesis testing)'이다(Eckstein, 2007;
$\operatorname{Lim} \& \mathrm{Kim}, 2014)$. 본 가창 프로그램의 LER 단계 또한 비슷한 과 정으로 진행되는데, Listen 단계가 ‘입력/연습’ 단계, Explore 단계 가‘피드백/주목’과 ‘가설형성' 단계, 마지막으로 Reproduce가 ‘가 설검증' 단계와 유사한 메커니즘으로 진행된다. 따라서 이러한 전략으로 중재한 결과 대상자들은 노래에서도 자가 모니터링을 활용하여 음고를 수정하여 산출하는 시도를 할 수 있었으며, 노 래 데이터의 사후검사를 통해 모든 대상자의 선율윤곽에 다양한 움직임의 변화 및 산출 음고의 주파수 범위가 증가하였다.

둘째, 본 프로그램에서 가창 시 선율윤곽 패턴으로 과제를 제 시하고, 음정 간격을 기준으로 단계적인 난이도를 설정한 전략은 의문문과 평서문의 억양패턴을 지각하는데 도움이 되었다. 그이 유는 기존 선행연구에서 나타난 $\mathrm{CI}$ 아동 대상의 가창 프로그램에 서는 두 개 음 내지의 짧은 단서의 음고변별 과제를 제시하였나 (Kim \& Choung, 2017; Kwon, 2016; Oh, 2015), CI 아동은 주파수 단서에 취약하여 짧은 단서의 음정간격을 변별하는데 한계가 있 다(Gfeller, 2002; Gfeller et al., 2006; Peng et al., 2008). 따라서 본 연 구에서는 긴 맥락에서 순차적으로 제시되는 음고를 단서로 제공 할 때 노래의 멜로디를 보다 정확하게 인지할 수 있도록 중재하 였다. 또한, 연구자는 연구대상자가 충분히 지각할 수 있는 음고 범위에서 점차 난이도를 높여 과제를 제시하였고 이를 통해 대상 자들은 과제의 맥락을 이해하고 의문문과 평서문의 차이를 인지 하는데 도움을 줄 수 있었다. 특히, 노래를 부를 때 사용되는 신체 기관의 움직임 및 기능은 언어를 산출하는 과정에서 사용되는 신 체 기관의 움직임과 기능을 요구하고 그 과정의 원리가 유사하기 때문에(Thaut, 2005), 선율 흐름 중심의 노래 활동은 억양 산출 시 필요로 하는 신체의 조음 기관 및 구강 기능을 연습할 수 있는 기 회를 제공한다. 이러한 영향으로 본 연구의 사후검사시 문장에서 의문문 문미 2 음절의 기울기가 상행 패턴으로 변화였고, $\mathrm{F} 0$ 기울 기, q-tone 기울기, $\mathrm{mA}$ 기울기에서 건청 아동과의 차이 값이 감소 하긴 하였으나, 통계상으로 유의미한 결과는 나타나지 않았다.

셋째, 기존의 음악 중재 선행연구가 CI 아동의 기초선과 중재 후의 변화치만 나타낸 반면(Kim \& Choung, 2017; Kwon, 2016; Oh, 2015), 본 연구에서는 비슷한 연령의 건청아동 그룹을 비교 
군으로 제시하여 적절한 비교 대상을 제공하였다는데 연구의 의 의가 있다. 그 밖에도 연구 중재 시 매 회기 직접 중재 보조로 참여 한 전문가들과 외부의 화면으로 중재를 관찰한 보호자들로부터 연구대상자들의 질적인 변화에 대한 보고가 있었다. 공통적인 내 용는 음악활동에 있어 내담자들이 매우 적극적으로 참여하였고, 언어 중재보다 음악을 통한 중재 시 언어 산출의 빈도가 증가하 였다는 것이었다.

이러한 긍정적인 변화에도 불구하고 본 연구는 영유아기 아동 의 발달 특성 상 인지수준이나 의사소통기능에 있어 개인 차이가 있으며 이로 인한 대상군의 동질성 확보에 한계가 있다. 또한 영 유아기 연령대를 대상으로 한 객관적인 검사도구 적용 또한 한계 가 있어 객관적 결과 해석에 있어 그 한계점이 있다. 그럼에도 불 구하고 영유아기는 발달상 매우 중요한 시기이며, 인공와우 아동 의 경우 수술 후 언어 및 음악적 발달이 일어나는 시기이기 때문 에 해당 연령을 대상으로 한 본 연구는 발달기 중재개입으로서 그 의의가 있다. 이에 후속 연구에서는 장기간 중재를 통해 자가 음성 모니터링을 응용한 가창 프로그램의 효과성을 추적하고, 발 달기 간 차이를 확인할 수 있는 활용방안을 제안하는 바이다. 또 한 본 연구는 음악이 가진 선율의 요소로 인해 CI 사용자의 1차적 필요인 의사소통 기술의 개선을 목표로 했다는 점에 의의가 있으 며, CI 아동의 음악인지 특성에 맞추어 구성된 자가목소리 모니 터링 접근으로 아동 $\mathrm{CI}$ 사용자 뿐 아니라 청소년, 성인 및 노인에 게도 적용해볼 수 있는 중재가 될 것으로 기대한다.

\section{References}

Allen, G. D., \& Arndorfer, P. M. (2000). Production of sentence-final intonation contours by hearing-impaired children. Journal of Speech and Hearing Research, 43(2), 441-455.

Beak, S. Y. (2010). Acoustic analysis on the intonation characteristics by infants with cochlear implants (Master's thesis). Dankook University, Korea.

Eckstein, G. T. (2007). A correlation of pronunciation learning strategies with spontaneous English pronunciation of adult ESL learners (Master's thesis). Birmingham Young University, London, UK.

Gardner, M. P. (1985). Mood states and consumer behavior: A critical review. Journal of Consumer Research, 12(3), 281-300.

Gfeller, K., Oleson, J., Knutson, J. F., Breheny, P., Driscoll, V., \& Olszewski, C. (2008). Multivariate predictors of music perception and appraisal by adult cochlear implant users. Journal of the American Academy of Audiol 프ogy, 19(2), 120-134.

Gfeller, K. E., Olszewski, C., Turner, C., Gantz, B., \& Oleson, J. (2006). Music perception with cochlear implants and residual hearing. Audiology and Neurotology, 11(Suppl. 1), 12-15.

Gfeller, K., Witt, S., Adamek, M., Mehr, M., Rogers, J., Stordahl, J., \& Ringgenberg, S. (2002). Effects of training on timbre recognition and appraisal by postlingually deafened cochlear implant recipients. Journal of the American Academy of Audiology, 13(3), 132-145.

Jang, M. O. (2003). The effect of singing-based verbal program on mentally retarded children's development of language ability (Master's thesis). Changwon National University, Korea.

Jeon, H. (2011) Longitudinal study of early vocal and phonetic development for cochlear implant infants (Master's thesis). Ewha womans University, Korea.

Kim, H. J., \& Chong, H. J. (2017). Interval-based singing program for improving the accuracy of pitch production in children with cochlear implants: A case study. Journal of Music and Human Behavior, 14(1), 1-16.

Kong, Y. Y., \& Zeng, F. G. (2006). Temporal and spectral cues in Mandarin tone recognition. The Journal of the Acoustical Society of America, 120(5), 2830-2840.

Krashen, S. (1989). We acquire vocabulary and spelling by reading: Additional evidence for the input hypothesis. The Modern Language Journal, 73(4), 440-464.

Kwon, J. O. (2016). The influence of singing nursery rhyme songs on the rhymes for cochlear implants in children (Master's thesis). Sookmyung Women's University, Korea.

Lee, H. J., \& Seong, C. J. (2019). Prosodic characteristics of likable utterance with respect to the public media materials. Jounal of Linguistic Society of Korea, 83, 119-148.

Lee, J. E., \& Heo, S. D. (2016). Satisfaction of listening in cochlear implantee. The Journal of Korean Academy of Medicine \& Therapy Science, 8(2), 85-93.

Lim, W. Y., \& Kim, Y. (2014). A study on the correlation between advanced Korean learners' pronunciation proficiency and strategy use. Journal of Korean Language Education, 25(4), 189-218.

Looi, V., Gfeller, K., \& Driscoll, D. V. (2012). Music appreciation and training for cochlear implant recipients: A review. In Seminars in Hearing, 33(4), 307-334.

Oh, E. J. (2012). The influence of cochlear implanted children's musical expressing ability on the intonation of assertive and interrogative sentences (Master's thesis). Chungnam National University, Korea.

Oh, S. (2015). Melody recognition by adults with cochlear implants (Master's thesis). Ewha womans University, Korea.

Peng, S. C., Tomblin, J. B., \& Turner, C. W. (2008). Production and perception of speech intonation in pediatric cochlear implant recipients and individuals with normal hearing. Ear and Hearing, 29(3), 336-351.

Seong, C. J. (2016). Script_slope_measurer.praat (version C-2016027236) [Computer program]. Retrieved from https://blog.naver. com/cj_seong/221409276859

Seo, Y. O. (2010). The effects on the improvement of prosody disposition through the chant program for the cochlear implant 
children (Master's thesis). Daegu University, Korea.

Thaut, M. H. (2005). The future of music in therapy and medicine. Annals of the New York Academy of Sciences, 1060(1), 303-308.

Tye-Murray, N. (2003). Conversational fluency of children who use cochlear implants. Ear and Hearing, 24(1), 82S-89S.

Yoo, H. S. (2003). The comparison of pitch production between children with cochlear implant and normal hearing children (Master's thesis). Hallym University, Korea.

\section{- 김성경 (Sung Keong Kim)}

소리의원 소리와우재활실 음악치료사

서울특별시 광진구 천호대로 592 광명빌딩

Tel: $070-4881-4800$

Email: lightsaltsk@gmail.com

관심분야: 청각장애 음악치료, 음악과 재활, 청각학

- 김수지 (Soo Ji Kim) 교신저자

이화여자대학교 교육대학원 음악치료교육전공 부교수

서울특별시 서대문구 이화여대길 52

Tel: 02-3277-6916

Email: specare@ewha.ac.kr

관심분야: 신경학적 음악치료, 음악과 재활, 인지노화 


\title{
자가음성 모니터링을 응용한 가창 프로그램이 인공와우이식 아동의 억양과 음고 변화에 미치는 영향
}

\author{
김 성 경 ${ }^{1} \cdot$ 김 수 지 ${ }^{2}$
}

${ }^{1}$ 소리의원 소리와우재활실, ${ }^{2}$ 이화여자대학교 교육대학원 음악치료교육전공

\begin{abstract}
국문초록
본 연구는 인공와우아동을 대상으로 자가음성 모니터링(self-voice monitoring)을 응용한 가창 프로그램을 시행하여 억양의 개선과 음고 산출의 변화에 미치는 영향을 알아보기 위함이다. 연구대상자는 모집된 19 명의 아동 중 참여 기준을 충족하고 본인 및 보호자가 자발적인 참여 의사를 표현한 7명이 최종으로 선정되었다. 연구자는 CI 집단과 비교하기 위하여 같은 연령의 건청 아동 6 명을 모집하였다. 자가음성 모니터링을 응용한 가창은 노래를 녹음하여 들어보고(listen), 음성의 음고 진행방향과 숨쉬기 구간 및 음질을 확인한(explore) 다음, 목소리를 수정하여 의도한 대로 재산출하는(reproduce) 세 단계로 구성되어 있다. 데이터는 문장과 노래로 나누어 측정하였다. 문장은 발화시 간과 억양 기울기 및 산출 음고의 주파수 변화, 노래는 프레이즈(phrase) 구간 내 평균 음고의 주파수의 데이터를 수 집하여 선율윤곽과 산출 주파수 범위를 측정한 후 건청집단과 비교하였다. 연구 결과 문장 분석에서 인공와우 아 동 집단의 사후검사 시 의문문의 문미 2 음절의 억양 기울기 및 패턴이 건청 아동과 같이 상행하는 윤곽으로 변화되 었으며, 노래 데이터에서는 음고의 도약 및 산출 음고의 주파수 범위가 증가하였다. 이러한 결과는 인공와우 아동 을 대상으로 한 자가음성 모니터링을 응용한 가창 프로그램이 억양의 개선과 음고 산출 정확도의 효과적인 중재 방안이 될 수 있으며 이를 위한 지속적인 연구가 필요하다는 것을 시사한다.
\end{abstract}

핵심어: 인공와우, 인공와우이식아동, 억양, 음고, 자가음성 모니터링, 가창 프로그램

\section{참고문헌}

권정옥 (2016). 노래부르기가 인공와우 이식아동의 운율 개선에 미치는 영향. 숙명여자대학교 석사학위논문.

임우열, 김영주 (2014). 한국어 고급 학습자의 발음 숙달도와 발 음 학습 전략 사용 간의 관계 연구. 한국어 교육, 25(4), 189-218. 김효진, 정현주 (2017). 음정 모방 중심 노래부르기를 통한 인공 와우이식아동의 음고 산출 정확도 향상 사례. 인간행동과 음 악연구, 14(1), 1-16.

백세영 (2010). 인공와우이식 영아의 억양특성에 대한 음향학적 분석. 단국대학교 석사학위논문.

서영옥(2010). 챈트(Chant) 프로그램이 인공와우 이식 아동의 운 율개선에 미치는 효과. 대구대학교 석사학위논문.

오수진 (2015). 인공와우이식 성인의 선율재인 정확도와 음악적 특성. 이화여대학교 석사학위논문.

오은주 (2012). 인공와우(Cochlear Implant) 아동의 음악적 표현 력이 평서문과 의문문의 억양에 미치는 영향. 충남대학교 석 사학위논문.

유현수 (2003). 건청 아동과 인공 와우 수술을 한 아동의Pitch 산 출 비교. 한림대학교 석사학위논문.
이자은, 허승덕 (2016). 인공와우 사용자 듣기 만족도. 대한치료 과학회지, 8(2), 85-93.

이현정, 성철재 (2019). 호감(likable) 발화의 말소리 운율 특징. 언 어학, 83, 119-148.

장명옥 (2003). 노래부르기를 활용한 언어지도 프로그램이 정신 지체아의 언어능력 발달에 미치는 효과. 창원대학교 석사학 위논문.

전현주 (2011). 인공와우이식 영아의 발성 및 음소 발달 종단연 구. 이화여자대학교 석사학위논문. 